\title{
Article
}

\section{Antibiotic Susceptibility Profile and Tetracycline Resistance Genes Detection in Salmonella spp. Strains Isolated from Animals and Food}

\author{
Valeria Gargano ${ }^{1}\left(\mathbb{D}\right.$, Sonia Sciortino ${ }^{1, *}$, Delia Gambino ${ }^{1, *} \mathbb{C}$, Antonella Costa ${ }^{1}$, Vincenzo Agozzino ${ }^{1}(\mathbb{D}$, \\ Stefano Reale ${ }^{1}$, Rosa Alduina ${ }^{2}\left(\mathbb{D}\right.$ and Domenico Vicari ${ }^{1}[$ \\ 1 Istituto Zooprofilattico Sperimentale della Sicilia, 90129 Palermo, Italy; valeria.gargano@izssicilia.it (V.G.); \\ antonella.costa@izssicilia.it (A.C.); v.agozzino@libero.it (V.A.); stefano.reale@izssicilia.it (S.R.); \\ domenico.vicari@izssicilia.it (D.V.) \\ 2 Department of Biological, Chemical and Pharmaceutical Sciences and Technologies (STEBICEF), \\ University of Palermo, 90028 Palermo, Italy; valeria.alduina@unipa.it \\ * Correspondence: sonia.sciortino@izssicilia.it (S.S.); deliagamb@gmail.com (D.G.)
}

\section{check for} updates

Citation: Gargano, V.; Sciortino, S.; Gambino, D.; Costa, A.; Agozzino, V.; Reale, S.; Alduina, R.; Vicari, D. Antibiotic Susceptibility Profile and Tetracycline Resistance Genes Detection in Salmonella spp. Strains Isolated from Animals and Food. Antibiotics 2021, 10, 809. https:// doi.org/10.3390/antibiotics10070809

Academic Editors: Nicholas Dixon and Alastair Hay

Received: 21 April 2021

Accepted: 30 June 2021

Published: 2 July 2021

Publisher's Note: MDPI stays neutral with regard to jurisdictional claims in published maps and institutional affiliations.

Copyright: (c) 2021 by the authors. Licensee MDPI, Basel, Switzerland. This article is an open access article distributed under the terms and conditions of the Creative Commons Attribution (CC BY) license (https:/ / creativecommons.org/licenses/by/ $4.0 /)$.

\begin{abstract}
Salmonella spp. is among the leading causes of foodborne infections in humans and a large number of animals. Salmonella spp. is a pathogen involved in the dissemination of antimicrobial resistance because it can accumulate antibiotic resistance genes (ARGs). In this study, the antibiotic resistance profile to 15 antibiotics, belonging to six different classes, of 60 strains of Salmonella spp. collected from pets, farm animals, wildlife, and food in Sicily (Italy) was investigated by the KirbyBauer method. Given that almost $33.3 \%$ of the Salmonella spp. strains were resistant to tetracycline, Real-Time PCR analysis was applied on all the 60 strains to detect the presence of eight selected tet resistance genes. Besides, the presence of the int 1 gene, related to the horizontal gene transfer among bacteria, was also investigated in all the strains by Real-Time PCR analysis. Our data showed that $56 \%$ of the isolated strains harbored one or more tet resistance genes and that these strains were most frequently isolated from animals living in close contact with humans. Concerning int1, 17 strains $(28.3 \%)$ harbored this genetic element and eight of these simultaneously contained tet genes. The results of this study highlight the importance of using a molecular approach to detect resistance genetic determinants, whose spread can increase the diffusion of multidrug-resistant strains. Besides, the study of zoonotic bacteria such as Salmonella spp. which significantly contribute to ARGs dissemination should always follow a One Health approach that considers the health of humans, animals, and the environment to be closely related.
\end{abstract}

Keywords: Salmonella; antibiotic resistance; ARGs; tet genes; animals; food

\section{Introduction}

The genus Salmonella, represented by facultative anaerobe bacilli with flagella, includes 2579 different serotypes divided into two species, S. enterica and S. bongori [1]. Bacteria belonging to the genus Salmonella are etiological agents with $S$. Typhimurium and $S$. Enteritidis, which cause gastrointestinal infections [2]. Non-typhoidal Salmonella infections can occur in pets, including domestic reptiles (iguanas and aquatic turtles), farm animals (chickens, pigs, cattle, rodents, dogs, cats, chicks), wildlife, and humans; in the latter, they are responsible for more than $50 \%$ of total gastrointestinal infections and are one of the most frequent causes of foodborne outbreaks in the industrialized world. Animals are often asymptomatic or may have subclinical forms of infection, and can contribute to environmental contamination through the faecal release of Salmonella [3]. This infectious disease can reach humans from production animals through the food chain, by direct contact with animals or by exposure to water or crops contaminated with manure [4]. Household, nonconventional pets (e.g., hedgehogs) and wild animals can also have a 
role in human salmonellosis [5]. Besides, reptiles, frequently found as common pets, are considered a reservoir of Salmonella spp. and can be a source of non-typhoidal human salmonellosis [6]. The annual report on zoonoses and zoonotic agents edited by the European Food Safety Authority (EFSA) and the European Centre for Disease Prevention and Control (ECDC) provides an overview of the monitoring activities carried out in 36 European countries (28 EU Member States and 8 non-members). To date, Salmonella spp. infections represent the second largest zoonosis in UE. Additionally, the World Health Organization (WHO) recommends national and regional laboratories to conduct foodborne surveillance for this pathogen. The WHO is also promoting integrated antimicrobial resistance surveillance of pathogens in the food chain by collecting samples from humans, food, and animals and analyzing data across all sectors. Considering the pathogenic action of Salmonella and the possible role of animals as sources of food contamination and human infection, several European countries have implemented surveillance systems (Enter-Vet in Italy) to collect data on Salmonella spp. isolated from samples of veterinary origin.

Gastrointestinal infections caused by Salmonella spp. have a self-limiting course and are not treated with antibiotics in healthy subjects. However, in children, the elderly, and immunocompromised individuals, the use of these drugs is necessary to prevent serious systemic illness [7]. Tetracyclines are broad-spectrum antimicrobial drugs, exhibiting activity against a wide range of both Gram-positive and Gram-negative bacteria, and are currently used for therapy and prophylaxis for human infections and the prevention and control of bacterial infections in veterinary medicine [8]. The increasing incidence of resistance to tetracyclines in Salmonella spp. of human and animal origins has been reported worldwide [9]. The overuse of antibiotics for therapy and prophylaxis of human and food-producing animal infections has contributed to Salmonella spp. being resistant to many classes of antibiotics, including those of first choice for treating Salmonella infection in humans [10]. The misuse in veterinary medicine of tetracycline to treat infections in cattle, poultry, sheep, and swine, or even to promote the growth of some animal species, has contributed to the increase in both human and animal resistant isolates, and consequently to the greatly increased probability of clinical failure [11].

Therefore, antimicrobial resistance (AMR) is widespread in Salmonella spp. isolates, both of human origin and other sources [12]. AMR is increasing to dangerous levels in all parts of the world and is now a major risk to global health and food security [13-16]. AMR occurs naturally, but the overuse of antibiotics in humans and animals is accelerating the process $[15,17]$. Bacteria can become resistant after spontaneous changes or mutations in their genetic material [9] or through DNA acquisition from other bacteria, such as integrons (int) and plasmids that might play a key role in the spread of antibiotic resistance genes (ARGs) [18]. When a plasmid harboring ARGs is transferred into other bacteria, antibiotic resistance can spread easily and quickly among strains [19]. Besides, integrons, which are mobile genetic elements containing ARG cassettes, can integrate into chromosomes or plasmids by site-specific recombination $[20,21]$.

In Italy, Salmonella spp. strains showed higher resistance profiles than the European average, with sulfamethoxazole being ineffective in $44.9 \%$ of cases, followed by tetracycline (40.4\%) and ampicillin (37.4\%) [22]. Moreover, the latest EFSA report showed alarming values of resistance to the critically important antimicrobial (CIA), ciprofloxacin and cefotaxime and/or ceftazidime of $18.9 \%$ and $23.5-31.6 \%$, respectively [23].

Resistance to tetracycline can occur by several mechanisms: antibiotic efflux or modification, protection of the binding site or modification of $16 \mathrm{~S}$ rRNA at the tetracycline-binding site [24].

So far, several tet genes that contribute to tetracycline resistance in Salmonella spp. have been described. The most frequent types of tet genes belong to classes A, B, C, D and G. Many of these genes can be localized within mobile portions of the Salmonella genome, such as transposons or plasmids, and this allows them to be easily disseminated in the environment and transferred to other bacteria $[9,25]$. 
According to WHO, antibiotic-resistant bacteria in Europe kill about 33 thousand people each year [26]. To protect human health, the only way forward is the proper use of antibiotics and a timely monitoring of the spread of antibiotic resistance and the genes that contribute to determining it. Bacteria belonging to the genus Salmonella spp. can represent tangible reservoirs of ARG genes and contribute greatly to the selection of multidrug-resistant (MDR) bacteria [27]. The AMR is now recognized as a zoonosis, and represents a problem not only in hospitals; indeed AMR strains have been isolated in confined environments where the selective pressure exerted by the use of antibiotics is low [28-30]. Therefore, this study aims to contribute to the analysis of antibiotic resistance profiles of Salmonella spp. strains isolated from animals and food of animal origin, and to investigate the spread of tetracycline resistance genes. In fact, in an insular territory such as Sicily, where livestock breeding is mainly of extensive/breeding type, the transmission of zoonotic pathogens can occur between farm animals, wild animals, pets and humans and can be monitored. For these reasons, following a "One Health" approach, we collected data on strains isolated from various contexts.

\section{Results}

\subsection{Collected Salmonella Strains}

A total of 60 strains of Salmonella spp. from animals (livestock, pet, zoo animals, wild) and food of animal origin were collected. The origin and serotypes of Salmonella spp. isolated are shown in Table 1.

Table 1. Source and serotypes of Salmonella spp. strains analyzed.

\begin{tabular}{|c|c|c|}
\hline Origin & Serotypes Analyzed & Number of Strains \\
\hline \multirow{8}{*}{ Livestock Animals $(n=16)$} & S. Derby & 6 \\
\hline & S. Typhimurium Monophasic & \\
\hline & Variant & 3 \\
\hline & S. Muenster & 3 \\
\hline & S. Typhimurium & 1 \\
\hline & S. Elomrane & 1 \\
\hline & S. Montevideo & 1 \\
\hline & S. Kedougou & 1 \\
\hline \multirow{7}{*}{ Pets $(n=12)$} & S. Typhimurium & 6 \\
\hline & S. Goldcoast & 2 \\
\hline & S. Typhimurium Monophasic & 1 \\
\hline & Variant & 1 \\
\hline & S. Enteritidis & 1 \\
\hline & S. Elomrane & 1 \\
\hline & S. Schleissheim & 1 \\
\hline \multirow{6}{*}{ Zoo Animals $(n=8)$} & S. Typhimurium & 2 \\
\hline & S. Richmond & 2 \\
\hline & S. Potsdam & 1 \\
\hline & S. Kiambu & 1 \\
\hline & S. Infantis & 1 \\
\hline & S. Bahrenfeld & 1 \\
\hline \multirow{8}{*}{ Wild Animals $(n=8)$} & S. Newport & 1 \\
\hline & S. Heron & 1 \\
\hline & S. bongori & 1 \\
\hline & S. Elomrane & 1 \\
\hline & S. Veneziana & 1 \\
\hline & S. Abony & 1 \\
\hline & S. Tennessee & 1 \\
\hline & S. Enteritidis & 1 \\
\hline
\end{tabular}


Table 1. Cont.

\begin{tabular}{ccc}
\hline Origin & Serotypes Analyzed & Number of Strains \\
\hline & S. Infantis & 7 \\
& S. Bredeney & 2 \\
Food from Animal Origin & S. Kentucky & 2 \\
$(n=16)$ & S. Typhimurium & 1 \\
& S. Derby & 1 \\
& S. Newport & 1 \\
& S. Enteritidis & 1 \\
& S. Cardoner & 1 \\
\hline
\end{tabular}

\subsection{Antimicrobial Susceptibility}

All Salmonella isolates were susceptible to chloramphenicol, ciprofloxacin, cefotaxime, enrofloxacin, levofloxacin and ceftriaxone. None of the isolates showed resistance to clinically important antimicrobial agents, such as ceftriaxone, ciprofloxacin, amoxicillinclavulanic acid and imipenem. The results of antibiograms performed by the Kirby-Bauer method are reported in the Supplementary Table S1.

$33.3 \%(20 / 60)$ of the Salmonella isolates were resistant to tetracycline, with $S$. Typhimurium representing the majority of these isolates (9 isolates), and $21.6 \%(13 / 60)$ were resistant to ampicillin with $S$. Typhimurium ( 7 isolates) representing the most common serovar, as showed in Figure 1.

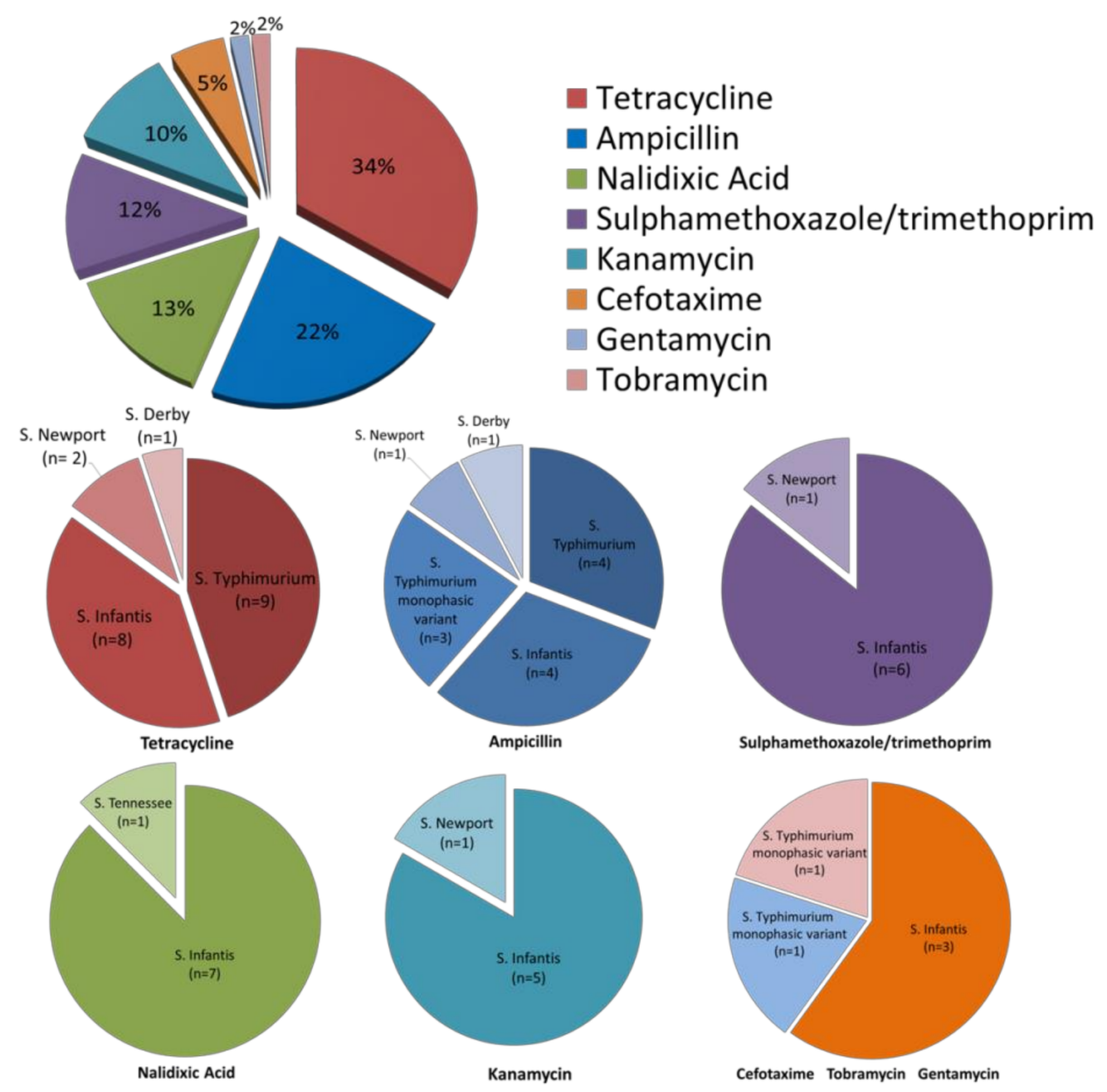

Figure 1. Phenotypic resistance profile of 60 Salmonella isolates. 
The first pie chart shows the percentage of phenotypic resistances of the 60 strains analyzed. The detail of the antibiotic-resistant serovars is shown in the pie charts below.

The details of the antibiogram results for each strain are shown in Table 2.

Table 2. Phenotypic resistance results.

\begin{tabular}{|c|c|c|}
\hline Id. Strain & Serotype & Phenotypic Resistance \\
\hline \multicolumn{3}{|c|}{ Livestock Animals $(n=3 / 16)$} \\
\hline S1 & S. Typhimurium Monophasic Variant & AMP \\
\hline $\mathrm{S} 2$ & S. Typhimurium Monophasic Variant & AMP \\
\hline S64 & S. Typhimurium Monophasic Variant & TE \\
\hline \multicolumn{3}{|c|}{ Pets $(n=6 / 12)$} \\
\hline S3 & S. Typhimurium & $\mathrm{CN}, \mathrm{TOB}, \mathrm{AMP}, \mathrm{TE}$ \\
\hline S19 & S. Typhimurium & TE \\
\hline S20 & S. Typhimurium & $\mathrm{TE}$ \\
\hline $\mathrm{S} 24$ & S. Typhimurium & AMP, TE \\
\hline S25 & S. Typhimurium & AMP, TE \\
\hline S32 & S. Typhimurium & $\mathrm{TE}$ \\
\hline \multicolumn{3}{|c|}{ Zoo Animals $(n=3 / 8)$} \\
\hline S26 & S. Typhimurium & $\mathrm{AMP}, \mathrm{TE}$ \\
\hline S27 & S. Typhimurium & AMP, TE \\
\hline S43 & S. Infantis & K, AMP, NA, SXT, TE \\
\hline \multicolumn{3}{|c|}{ Wild Animals $(n=2 / 8)$} \\
\hline $\mathrm{S} 4$ & S. Newport & $\mathrm{TE}$ \\
\hline S41 & S. Tennessee & NA \\
\hline \multicolumn{3}{|c|}{ Food from Animal Origin $(n=9 / 16)$} \\
\hline S58 & S. Newport & K, AMP, SXT, TE, \\
\hline $\mathrm{S} 62$ & S. Infantis & K, AMP, CTX, NA, TE \\
\hline S63 & S. Infantis & K, AMP, CTX, NA, SXT, TE \\
\hline S48 & S. Infantis & AMP, CTX, NA, SXT, TE \\
\hline S55 & S. Infantis & K, NA, SXT, TE \\
\hline S56 & S. Infantis & $\mathrm{TE}$ \\
\hline S68 & S. Infantis & NA, SXT, TE \\
\hline S69 & S. Infantis & K, NA, SXT, TE \\
\hline S47 & S. Derby & AMP, TE \\
\hline
\end{tabular}

Kanamycin (K); Gentamicin (CN); Tobramycin (TOB); Ampicillin (AMP); Cefotaxime (CTX); Nalidixic Acid (NA); Sulphamethoxazole/Trimethoprim (STX); Tetracycline (TE).

Multidrug resistance (MDR), defined as resistance to three or more tested classes of antibiotics, was observed in nine strains of Salmonella spp., with all these isolates resistant to tetracycline (Figure 2).

\subsection{Detection of Tetracycline Resistance Genes and Class-1 Integron}

Considering the percentage of tetracycline-resistant strains and the possibility of the spreading of ARGs by horizontal gene transfer, Real Time PCRs were conducted on the 60 Salmonella spp. strains to determine the presence of genetic determinants of tetracycline resistance and class 1 integron. This analysis showed that 41.7\% (25/60) of the analyzed strains harbored one or more tet resistance genes: 10 strains were from pets, 5 strains from livestock, 5 strains from zoo animals, 4 strains from food, while only 1 strain was isolated from a wild animal.

Among the strains analyzed, tet (A) was the most prevalent gene, present in 56\% $(14 / 25)$ of the strains harboring at least one tet gene, and tet $(\mathrm{A})$ gene was found alone in 9/14 strains, while it was in association with other tet genes in the remaining five strains. 


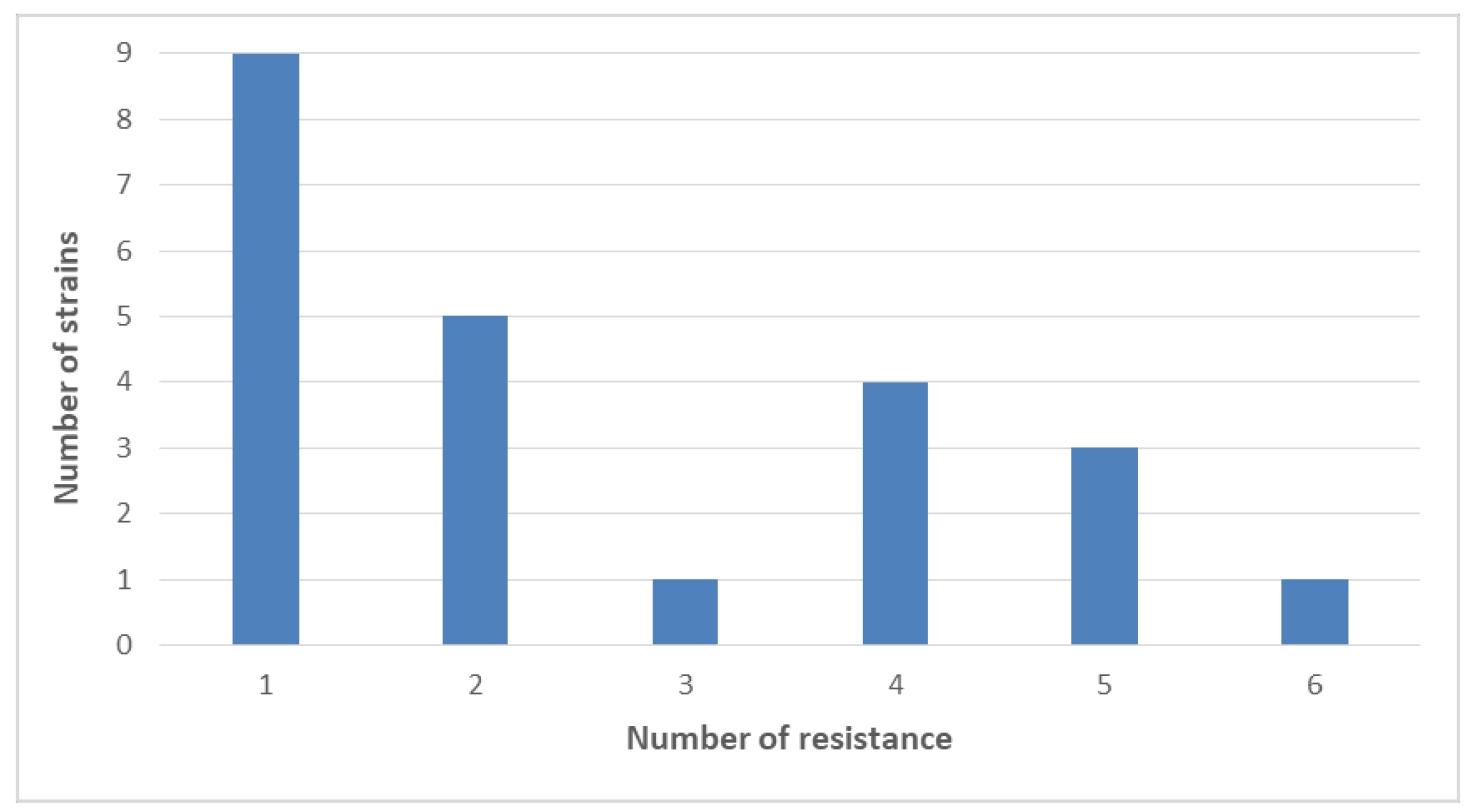

Figure 2. Number of resistant strains detected.

The tet $(\mathrm{G})$ was the second most represented gene, found alone or in association with other tet genes in 5/25 of the strains; while the tet (C) and tet (D) genes were found at the same frequency $(4 / 25)$ among the analyzed strains; finally, tet (B) gene was found in $3 / 25$ strains. The tet (E) gene was the least frequently detected, in fact it was harbored only by $2 / 25$ strains. Concerning int 1 gene, it was found in $17 / 60$ strains, 8 of which harbored at least one tet gene. Moreover, among the 25 strains that possessed at least one tet gene, only 11 were phenotipically resistant to tetracycline (Table 3 ) and nine tetracycline resistant strains did not contain any of the analyzed genes.

Table 3. Genotypic and phenotypic resistance to tetracycline results.

\begin{tabular}{|c|c|c|c|c|c|}
\hline Id. & Source & Serovar & Tetracycline Resistance Genes & int1 & $\begin{array}{c}\text { Tetracycline Phenotypic } \\
\text { Resistance }\end{array}$ \\
\hline S1 & \multirow{5}{*}{ Livestock } & S. Typhimurium monofasic variant & tet $(\mathrm{A})$ & int1 & $\mathrm{S}$ \\
\hline S7 & & S. Montevideo & tet (D) & - & $\mathrm{S}$ \\
\hline S11 & & S. Derby & tet $(\mathrm{G})$ & int1 & $\mathrm{S}$ \\
\hline S17 & & S. Muenster & tet (D) & - & $\mathrm{S}$ \\
\hline S54 & & S. Derby & tet $(\mathrm{E})$, tet $(\mathrm{D})$ & - & $\mathrm{S}$ \\
\hline S3 & \multirow{10}{*}{ Pets } & S. Typhimurium monofasic variant & tet $(\mathrm{B})$, tet $(\mathrm{G})$ & - & $\mathrm{R}$ \\
\hline S8 & & S. Goldcoast & tet $(\mathrm{A})$, tet $(\mathrm{D})$ & int1 & $\mathrm{S}$ \\
\hline S9 & & S. Goldcoast & tet $(\mathrm{A})$ & int1 & $S$ \\
\hline S19 & & S. Typhimurium & tet $(\mathrm{A})$, tet $(\mathrm{E})$, tet $(\mathrm{G})$, tet $(\mathrm{C})$ & - & $\mathrm{R}$ \\
\hline S20 & & S. Typhimurium & tet $(\mathrm{E})$, tet $(\mathrm{B})$, tet $(\mathrm{C})$ & - & $\mathrm{R}$ \\
\hline S24 & & S. Typhimurium & tet $(\mathrm{A})$ & - & $\mathrm{R}$ \\
\hline S25 & & S. Typhimurium & tet $(\mathrm{A})$, tet $(\mathrm{G})$ & - & $\mathrm{R}$ \\
\hline S30 & & S. Enteritidis & tet $(\mathrm{A})$, tet $(\mathrm{E})$ & int1 & $S$ \\
\hline S32 & & S. Typhimurium & tet (A) & - & $\mathrm{R}$ \\
\hline S35 & & S. Elomrane & tet $(\mathrm{C})$ & - & $\mathrm{S}$ \\
\hline S15 & \multirow{6}{*}{ Zoo } & S. Kiambu & tet $(\mathrm{G})$ & - & $\mathrm{S}$ \\
\hline S26 & & S. Typhimurium & tet $(\mathrm{A})$ & - & $\mathrm{R}$ \\
\hline S27 & & S. Typhimurium & tet $(\mathrm{A})$ & - & $\mathrm{R}$ \\
\hline S29 & & S. Richmond & tet $(\mathrm{A})$ & - & $S$ \\
\hline $\mathrm{S} 43$ & & S. Infantis & tet $(\mathrm{A})$ & int1 & $\mathrm{R}$ \\
\hline S21 & & S. bongori & tet $(\mathrm{C})$ & - & S \\
\hline S47 & Wildlife & S. Derby & tet $(\mathrm{G})$ & & $\mathrm{R}$ \\
\hline S59 & \multirow{3}{*}{ Food } & S. Cardoner & tet (B) & - & S \\
\hline S67 & & S. Enteritidis & tet (A) & int1 & $\mathrm{S}$ \\
\hline S69 & & S. Infantis & tet $(\mathrm{A})$ & int1 & $\mathrm{R}$ \\
\hline
\end{tabular}




\section{Discussion}

This study demonstrates a larger diffusion of tetracycline resistance genes with respect to the tetracycline-resistance profile of 60 Salmonella spp. strains. The strains analyzed belonged to 44 isolated from animals (livestock, pets, zoo or wildlife) and 16 from food.

S. enterica was the most prevalent isolated species; in fact, only one Testudo hermanni harbored S. bongori. Among S. enterica strains, the prevalent serovars were Typhimurium $(23.3 \%)$, including the monophasic variant, and Infantis (13.3\%), as shown in Figure 1. Indeed, Typhimurium and Infantis serotypes are the most prevalent species found in humans and animals, and are considered "zoonotic salmonellae" [22]. Among the 60 strains, $23(38.3 \%)$ showed resistance to at least one antibiotic among the 15 tested; in particular, the antibiotics for which a higher percentage of resistance was found were tetracycline $(33.3 \%)$ and ampicillin $(21.6 \%)$, widely used in human and veterinary medicine. In contrast, low rates of resistance were observed toward gentamicin and tobramycin (1.6\%), cefotaxime $(5 \%)$, kanamycin $(10 \%)$, sulfamethoxazole/trimethoprim $(11.6 \%)$, and nalidixic acid (13.3\%).

Most of the strains that showed phenotypic resistance to tetracycline belonged to the serovars monitored by EFSA for antibiotic resistance [12]. According to the comprehensive antibiotic resistance database (https:/ / card.mcmaster.ca, accessed on date 10 February 2021), a bioinformatic database of resistance genes, we have chosen eight of the most studied genes associated with tetracycline resistance, six of which encode for proteins involved in the regulation of efflux pumps, with two for proteins of ribosomal protection. By comparing results obtained using Real Time PCR to detect tet resistance genes with the results of tetracycline-resistance profile on 60 strains of Salmonella spp., we found that $41.6 \%(25 / 60)$ of the strains harbored one or more tetracycline resistance gene confirming what has been well documented by other studies [31,32]; conversely, the Kirby Bauer test evidenced that $33.3 \%$ of strains were resistant. Indeed, the presence of tet genes was revealed in 14 phenotypically susceptible strains. This result could be explained by the fact that not only efflux pumps contribute to tetracycline resistance but also other mechanisms, as suggested in other reports [33]. Moreover, we can surmise that the tet genes (tets $(A)$ and $(B)$ ) detected in 14 tetracycline-sensitive strains are not expressed in the experimental conditions used in this study. Furthermore, the Kirby Bauer test showed the presence of nine MDR strains: one $S$. Typhimurium monophasic variant from pets, and one $S$. Infantis from food resistant to three classes; six $S$. Infantis and one $S$. Newport, all from food resistant to four classes; one $S$. Infantis from zoo animals resistant to five classes (Figure 2).

All tet genes detected in this study (tet (A), tet (B), tet (C), tet (D), tet (E), tet (G)) are implicated in the mechanism of tetracycline extrusion from the bacterial cell, that represents a common strategy of tetracycline resistance. We did not detect tet $(\mathrm{O})$ and tet $(W)$, that were recently found to be diffused in Gram-negative bacteria isolated from water samples of various origin [34]. The most frequently detected gene was tet (A), harbored by $14 / 25$ $(56 \%)$ strains; this gene encodes a subunit of the tetracycline efflux pump found in many species of Gram-negative bacteria [35]. Thirteen of the strains that possessed tet (A), eight of which also showed phenotypic resistance to tetracyclines, were obtained from animals living in close contact with humans or from food: $7 / 10$ pets, $4 / 6$ zoo animals, $2 / 3$ food samples. The detection of Salmonella spp. strains with tetracycline resistance genes in dogs could be interesting because often these pets share the dwelling, and in general live in close contact with their owners. This occurrence is relevant in the case of bacterial infections with oral-fecal transmission, such as Salmonella spp. Moreover, strains with these characteristics were isolated from animals that lived in a zoo, a place frequented by people, especially children, where the possibility of AMR spreading could increase.

Some serovars of $S$. enterica harboring tet genes have been isolated from livestock; among these five strains were harbored antibiotic resistance genes: two strains of $S$. Derby, one of $S$. Typhimurium monophasic variant, one of $S$. Montevideo and one of $S$. Muenster. Among these strains, the most representative gene was tet (D) $(3 / 5)$. The presence of these genes in strains from livestock is not surprising, especially as these animals come into 
close contact with farmers. Certainly, this fact should be better investigated both because a transmission from these animals to humans and vice versa is possible, and also because during grazing these animals can contribute with their feces to the spread of ARGs on very large areas.

Other strains of Salmonella spp. examined in this study came from terrestrial wildlife; concerning these only a strain of $S$. Derby harbored tet $(\mathrm{G})$, a tetracycline efflux protein found in Gram-negative bacteria. The encoding gene is found in both chromosomal and plasmid DNA where it is frequently linked to other genes which encode proteins that can confer florphenicol/chloramphenicol, sulfamethoxazole, and chloramphenicol resistance [36].

The tet(A) has been shown to be the most common genetic component in tetracyclineresistant Escherichia coli and Salmonella spp. [37]. Generally remaining in mobile genetic components (integrons, transposons, and plasmids), tet (A) can be easily transferred to different bacteria [38]. The ability of the tet (A) gene to spread freely in farm animals compared with other tet genes has been widely demonstrated [39]. Our results seem to confirm that this gene can be spread more easily in the environment.

Our data are in accordance with other reports, describing that tetracycline resistance is related to plasmid incompatibility; indeed, we never found strains containing simultaneously tet (A) and tet (B) genes either tet (C) and tet (D) [40]. Moreover, our data seem to confirm that tet $(\mathrm{E})$ would not spread as easily as other tet genes since it is usually located on the chromosome on large, non-conjugative plasmids [41].

The presence of tetracycline resistance genes is alarming, since Salmonella can persist for months in adverse conditions and in the environment (i.e., non-drinking water), and thus can become responsible for intestinal infectious diseases in humans that often are considered as healthy carriers [3,28,29].

In addition to their high pathogenic potential, bacteria of the Salmonella genus are of particular interest for their contribution in the spread of antibiotic resistance, as they are able to accumulate and spread ARGs [42]. The genetic plasticity of Salmonella bacteria allows them to accumulate and disseminate ARGs that often are located in plasmids that carry also other virulence genes $[43,44]$. Thanks to this characteristic, the genus Salmonella spp. can easily transfer resistance genes horizontally to other bacteria [45]. Furthermore, the interaction between class 1 integrons and plasmids contributes to the ability of these bacteria to be reservoirs of ARGs [20,21]. For these reasons, the detection of int1 was also conducted on all isolated strains. Our results showed that the strains isolated from wildlife did not harbor the int1 gene, confirming the low presence of this genetic element in other bacterial strains collected from wild animals in Sicily [46]. The presence of int1 was identified in 17/60 strains, in 8 of these it was in association with one or more tet genes, indicating a warning for the spread of ARGs, as noted elsewhere [47]. The frequency of class I integrons has been postulated as an indicator of anthropogenic pollution in the environment [48]. Indeed, the widespread presence of the int1 gene in our samples highlights the potential transfer of ARGs between bacterial strains and their spread could increase the risk to human health. Concerning the high level of attention to antimicrobial resistance and the ease with which ARGs spread, from a One Health perspective it is important to monitor the presence of these genes, especially in zoonotic bacteria. Our data show that the majority of strains harboring antibiotic resistance genes have been isolated from animals in close contact with humans and that these animals could contribute significantly to the spreading of ARGs between bacteria.

\section{Materials and Methods}

\subsection{Isolation and Identification of Salmonella spp.}

Isolation of Salmonella spp. was conducted using enrichment broths and selective media as suggested by the OIE manual [3]. Colonies that could be attributed to Salmonella were identified at the genus level by biochemical testing (API20E ${ }^{\circledR}$, bioMérieux, Craponne, France). Subsequently, the serotype of the Salmonella strains was determined using somatic 
$\mathrm{O}$ and flagellar $\mathrm{H}$ antisera (Becton Dickinson, Milano, Italy) [49]. All the media were purchased from Oxoid (Milano, Italy).

\subsection{Antimicrobial Susceptibility by the Disk Diffusion Method}

Antimicrobial susceptibility testing of 60 Salmonella isolates was performed on MuellerHinton agar (Oxoid, Milano, Italy) by disc diffusion method (Kirby-Bauer), according to Clinical and Laboratory Standard Institute (CLSI) guidelines [50]. A set of 16 antibiotics has been defined: sulfamethoxazole/trimethoprim (STX, $25 \mu \mathrm{g})$, kanamycin $(\mathrm{K}, 30 \mu \mathrm{g})$, gentamicin $(\mathrm{CN}, 10 \mu \mathrm{g})$, nalidixic acid (NA, $30 \mu \mathrm{g})$, tetracycline (TE, $30 \mu \mathrm{g})$, ampicillin (AMP, $10 \mu \mathrm{g}$ ), chloramphenicol (C, $10 \mu \mathrm{g}$ ), ciprofloxacin (CIP, $5 \mu \mathrm{g})$, cefotaxime (CTX, 30 $\mu \mathrm{g}$ ), amoxicillin/clavulanic acid (AMC, $30 \mu \mathrm{g}$ ), enrofloxacin (ENR, $5 \mu \mathrm{g}$ ), tobramycin (TOB, $10 \mu \mathrm{g}$ ), levofloxacin (LEV, $5 \mu \mathrm{g}$ ), imipenem (IPM, $10 \mu \mathrm{g}$ ) and ceftriaxone (CRO, $30 \mu \mathrm{g})$ disks (Oxoid, Milano, Italy) were used.

A 0.5 McFarland bacterial suspension was prepared from each isolate in saline solution and spread on Mueller-Hinton agar. After incubation at $37^{\circ} \mathrm{C}$ for $24 \mathrm{~h}$, the isolates were classified as resistant (R), susceptible (S) or intermediate (I) after determination of the diameters of inhibition zones. The interpretation of the results was performed following CLSI indications [50].

\subsection{DNA Extraction}

Bacterial isolates were grown in Agar Nutrient (Oxoid, Milano, Italy) overnight. Two colonies from each plate were suspended in $100 \mu \mathrm{l}$ of PrepMan ${ }^{\mathrm{TM}}$ Ultra Sample Preparation Reagent (Thermo Fisher Scientific, Waltham, MA, USA) following manufacturer's instructions. The DNA obtained was stored at $-20^{\circ} \mathrm{C}$ until analysis.

\subsection{Detection of Antibiotic Resistance Genes and Class-1 Integron}

PCR reactions were carried out using $10 \mathrm{ng}$ of DNA template and $0.5 \mu \mathrm{M}$ of forward and reverse primers listed in Table 4, in a total volume of $25 \mu \mathrm{L}$ of $1 \times$ of Advanced Universal SYBR Green Supermix (Bio-Rad Laboratories, Hercules, CA, USA), to amplify eight antibiotic resistance genes and the mobile element int1. The amplification of the $16 \mathrm{~S}$ rDNA was used as a positive control. All samples considered positive to Real-Time PCR were verified by electrophoresis analysis on E-Gel ${ }^{\mathrm{TM}} \mathrm{Go}$ ! Agarose Gels, 2\% (Thermo Fisher Scientific, Waltham, MA, USA).

To confirm the identity of the amplicons from tetracycline-susceptible strains, one amplicon of each tet gene was sequenced. DNA sequences were determined using the dideoxy chain termination method with a commercial DNA sequencing kit (BigDye ${ }^{\mathrm{TM}}$ Terminator v3.1 Cycle Sequencing Kit, Applied Biosystems ${ }^{\mathrm{TM}}$ (Thermo Fisher Scientific, Waltham, MA, USA) according to the manufacturer's instructions. The obtained sequences were analyzed for nucleotide sequence identity by comparing them with reference strains in the GenBank database using the Basic Local Alignment Search Tool (BLAST) and The Comprehensive Antibiotic Resistance Database (The Comprehensive Antibiotic Resistance Database (https:/ / card.mcmaster.ca, accessed on date 2 October 2021). Finally, the sequenced samples were used as positive controls to confirm by real-time PCR the presence of tet genes in tetracycline-susceptible strains. For this purpose, a sample was considered positive if the number of threshold cycles $(\mathrm{Ct})$ was less than 35 cycles and if the melting curve had the same temperature and was overlapping with that one of the positive control (Supplementary Table S2). 
Table 4. Primers and the annealing temperatures used in this study.

\begin{tabular}{|c|c|c|c|c|c|}
\hline Target Gene & Primer Sequence $\left(5^{\prime}-3^{\prime}\right)$ & Function & $\begin{array}{c}\text { Annealing } \\
\text { Temperature }\left({ }^{\circ} \mathrm{C}\right)\end{array}$ & $\begin{array}{l}\text { Amplicon } \\
\text { Size (bp) }\end{array}$ & References \\
\hline tet $(\mathrm{A})$ & $\begin{array}{l}\text { GCTACATCCTGCTTGCCTTC } \\
\text { CATAGATCGCCGTGAAGAGG }\end{array}$ & Efflux & 60 & 210 & {$[51]$} \\
\hline tet (B) & $\begin{array}{l}\text { TTGGTTAGGGGCAAGTTTTG } \\
\text { GTAATGGGCCAATAACACCG }\end{array}$ & Efflux & 60 & 659 & {$[51]$} \\
\hline tet $(\mathrm{C})$ & $\begin{array}{l}\text { CTTGAGAGCCTTCAACCCAG } \\
\text { ATGGTCGTCATCTACTGCC }\end{array}$ & Efflux & 60 & 418 & [51] \\
\hline tet (D) & $\begin{array}{l}\text { AAACCATTACGGCATTCTGC } \\
\text { GACCGGATACACCATCCATC }\end{array}$ & Efflux & 60 & 787 & [52] \\
\hline tet $(\mathrm{E})$ & $\begin{array}{l}\text { AAACCACATCCTCCATACGC } \\
\text { AAATAGGCCACAACCGTCAG }\end{array}$ & Efflux & 60 & 278 & [52] \\
\hline tet $(\mathrm{G})$ & $\begin{array}{c}\text { GCTCGGTGGTATCTCTGCTC } \\
\text { AGCAACAGAATCGGGAACAC }\end{array}$ & Efflux & 60 & 844 & [52] \\
\hline tet $(\mathrm{O})$ & $\begin{array}{l}\text { GGAGGGGTTCAACCACAAAG } \\
\text { CTATGTAAATAAAATGGATAG }\end{array}$ & Ribosomal protection & 55 & 88 & [53] \\
\hline tet $(\mathrm{W})$ & $\begin{array}{l}\text { ACATCATTGATACTCCAGGTCACG } \\
\text { TTTCACTTTGTGGTTGAACCCCTC }\end{array}$ & Ribosomal protection & 60 & 142 & [53] \\
\hline int1 & $\begin{array}{l}\text { CCT CCC GCA CGA TGA TC } \\
\text { TCC ACG CAT CGT CAG GC }\end{array}$ & Class 1 integron & 60 & 280 & [53] \\
\hline $16 S r D N A$ & $\begin{array}{l}\text { CGGTGAATACGTTCYCGGG } \\
\text { GHTACCTTGTTACGACTT }\end{array}$ & Positive Control & 55 & 142 & [47] \\
\hline
\end{tabular}

\section{Conclusions}

The presence of Salmonella spp. in pets, or in animals living in close contact with humans, like livestock and zoo animals, suggests that the spread of these bacteria in animals should be better investigated. In fact, although infections caused by non-typhoidal Salmonella can have a paucisymptomatic or asymptomatic course in humans and do not cause disease in most animals, these bacteria would play a very important role in the environmental dissemination of tetracycline antibiotic resistance genes.

Therefore, the study of bacteria belonging to the genus Salmonella should always be done through a One Health approach, which considers the health of people, animals and the environment closely related, as these bacteria can be considered "sentinel" microorganisms for the spread of ARGs.

Supplementary Materials: The following are available online at https:/ /www.mdpi.com/article/10 .3390 /antibiotics10070809/s1, Table S1: Results of antimicrobial susceptibility by the Kirby-Bauer method; Table S2: Real-time PCR data for tet (A) and tet (B) genes in tetracycline-susceptible strains.

Author Contributions: Conceptualization, V.G., D.G. and S.S.; methodology, V.G., S.S., D.G.; formal analysis, V.G., S.S., V.A., S.R. and D.G.; investigation, V.G., D.G. and S.S.; resources, D.V.; data curation, V.G., D.G., S.S. and R.A.; writing—original draft preparation, V.G., D.G. and S.S.; writing—review and editing, V.G., S.S., D.G. and R.A.; visualization, A.C.; supervision, D.V. and A.C. All authors have read and agreed to the published version of the manuscript.

Funding: This research received no external funding.

Institutional Review Board Statement: Not applicable.

Informed Consent Statement: Not applicable.

Data Availability Statement: All data discussed are contained in the article.

Conflicts of Interest: The authors declare no conflict of interest. 


\section{References}

1. Tindall, B.J.; Grimont, P.A.D.; Garrity, G.M.; Euzéby, J.P. Nomenclature and Taxonomy of the Genus Salmonella. Int. J. Syst. Evol. Microbiol. 2005, 55, 521-524. [CrossRef] [PubMed]

2. Post, A.S.; Diallo, S.N.; Guiraud, I.; Lompo, P.; Tahita, M.C.; Maltha, J.; Van Puyvelde, S.; Mattheus, W.; Ley, B.; Thriemer, K.; et al. Supporting Evidence for a Human Reservoir of Invasive Non-Typhoidal Salmonella from Household Samples in Burkina Faso. PLoS Negl. Trop. Dis. 2019, 13, e0007782. [CrossRef]

3. International Office of Epizootics; Biological Standards Commission. In Manual of Diagnostic Tests and Vaccines for Terrestrial Animals: (Mammals, Birds and Bees); OIE: Paris, France, 2018; ISBN 978-92-95108-18-9.

4. Eng, S.-K.; Pusparajah, P.; Ab Mutalib, N.-S.; Ser, H.-L.; Chan, K.-G.; Lee, L.-H. Salmonella: A Review on Pathogenesis, Epidemiology and Antibiotic Resistance. Front. Life Sci. 2015, 8, 284-293. [CrossRef]

5. Guardabassi, L. Pet Animals as Reservoirs of Antimicrobial-Resistant Bacteria: Review. J. Antimicrob. Chemother. 2004, 54, 321-332. [CrossRef]

6. $\quad$ Damborg, P.; Broens, E.M.; Chomel, B.B.; Guenther, S.; Pasmans, F.; Wagenaar, J.A.; Weese, J.S.; Wieler, L.H.; Windahl, U.; Vanrompay, D.; et al. Bacterial Zoonoses Transmitted by Household Pets: State-of-the-Art and Future Perspectives for Targeted Research and Policy Actions. J. Comp. Pathol. 2016, 155, S27-S40. [CrossRef]

7. Vilela, F.P.; Gomes, C.N.; Passaglia, J.; Rodrigues, D.P.; Costa, R.G.; Tiba Casas, M.R.; Fernandes, S.A.; Falcão, J.P.; Campioni, F. Genotypic Resistance to Quinolone and Tetracycline in Salmonella Dublin Strains Isolated from Humans and Animals in Brazil. Microb. Drug Resist. 2018, 25, 143-151. [CrossRef] [PubMed]

8. McManus, P.S.; Stockwell, V.O.; Sundin, G.W.; Jones, A.L. Antibiotic Use in Plant Agriculture. Annu. Rev. Phytopathol. 2002, 40, 443-465. [CrossRef]

9. Frech, G.; Schwarz, S. Molecular Analysis of Tetracycline Resistance in Salmonella Enterica Subsp. Enterica Serovars Typhimurium, Enteritidis, Dublin, Choleraesuis, Hadar and Saintpaul: Construction and Application of Specific Gene Probes. J. Appl. Microbiol. 2000, 89, 633-641. [CrossRef] [PubMed]

10. Elnekave, E.; Hong, S.L.; Lim, S.; Boxrud, D.; Rovira, A.; Mather, A.E.; Perez, A.; Alvarez, J. Transmission of Multidrug-Resistant Salmonella Enterica Subspecies Enterica 4,[5],12:I:- Sequence Type 34 between Europe and the United States. Emerg. Infect. Dis. 2020, 26, 3034-3038. [CrossRef] [PubMed]

11. Chopra, I.; Roberts, M. Tetracycline Antibiotics: Mode of Action, Applications, Molecular Biology, and Epidemiology of Bacterial Resistance. Microbiol. Mol. Biol. Rev. 2001, 65, 232-260. [CrossRef]

12. European Food Safety Authority; European Centre for Disease Prevention and Control The European Union Summary Report on Antimicrobial Resistance in Zoonotic and Indicator Bacteria from Humans, Animals and Food in 2017/2018. EFSA J. 2020, 18. [CrossRef]

13. Vitale, M.; Scatassa, M.L.; Cardamone, C.; Oliveri, G.; Piraino, C.; Alduina, R.; Napoli, C. Staphylococcal Food Poisoning Case and Molecular Analysis of Toxin Genes in Staphylococcus Aureus Strains Isolated from Food in Sicily, Italy. Foodborne Pathog. Dis. 2015, 12, 21-23. [CrossRef]

14. Vitale, M.; Gaglio, S.; Galluzzo, P.; Cascone, G.; Piraino, C.; Di Marco Lo Presti, V.; Alduina, R. Antibiotic Resistance Profiling, Analysis of Virulence Aspects and Molecular Genotyping of Staphylococcus Aureus Isolated in Sicily, Italy. Foodborne Pathog. Dis. 2018, 15, 177-185. [CrossRef] [PubMed]

15. Vitale, M.; Galluzzo, P.; Buffa, P.G.; Carlino, E.; Spezia, O.; Alduina, R. Comparison of Antibiotic Resistance Profile and Biofilm Production of Staphylococcus Aureus Isolates Derived from Human Specimens and Animal-Derived Samples. Antibiotics 2019, 8, 97. [CrossRef] [PubMed]

16. Sciortino, S.; Arculeo, P.; Alio, V.; Cardamone, C.; Nicastro, L.; Arculeo, M.; Alduina, R.; Costa, A. Occurrence and Antimicrobial Resistance of Arcobacter Spp. Recovered from Aquatic Environments. Antibiotics 2021, 10, 288. [CrossRef] [PubMed]

17. Peterson, E.; Kaur, P. Antibiotic Resistance Mechanisms in Bacteria: Relationships Between Resistance Determinants of Antibiotic Producers, Environmental Bacteria, and Clinical Pathogens. Front. Microbiol. 2018, 9, 2928. [CrossRef]

18. Thomas, C.M.; Nielsen, K.M. Mechanisms of, and Barriers to, Horizontal Gene Transfer between Bacteria. Nat. Rev. Microbiol. 2005, 3, 711-721. [CrossRef]

19. Aarestrup, F.M. Veterinary Drug Usage and Antimicrobial Resistance in Bacteria of Animal Origin. Basic Htmlent Glyphamp Asciiamp Clin. Pharmacol. Htmlent Glyphamp Asciiamp Toxicol. 2005, 96, 271-281. [CrossRef]

20. Wang, W.; Wang, L.; Su, J.; Xu, Z. Antibiotic Susceptibility, Biofilm-Forming Ability, and Incidence of Class 1 Integron of Salmonella Spp., Escherichia Coli, and Staphylococcus Aureus Isolated from Various Foods in a School Canteen in China. Foodborne Pathog. Dis. 2020, 17, 269-275. [CrossRef]

21. Zhao, H.; Chen, W.; Xu, X.; Zhou, X.; Shi, C. Transmissible ST3-IncHI2 Plasmids Are Predominant Carriers of Diverse Complex IS26-Class 1 Integron Arrangements in Multidrug-Resistant Salmonella. Front. Microbiol. 2018, 9, 2492. [CrossRef]

22. European Food Safety Authority and European Centre for Disease Prevention and Control (EFSA and ECDC) The European Union Summary Report on Trends and Sources of Zoonoses, Zoonotic Agents and Food-borne Outbreaks in 2017. EFSA J. 2018, 16. [CrossRef]

23. European Food Safety Authority; European Centre for Disease Prevention and Control The European Union One Health 2019 Zoonoses Report. EFSA J. 2021, 19. [CrossRef] 
24. Connell, S.R.; Tracz, D.M.; Nierhaus, K.H.; Taylor, D.E. Ribosomal Protection Proteins and Their Mechanism of Tetracycline Resistance. Antimicrob. Agents Chemother. 2003, 47, 3675-3681. [CrossRef]

25. Hall, R.M. Salmonella Genomic Islands and Antibiotic Resistance in Salmonella Enterica. Future Microbiol. 2010, 5, 1525-1538. [CrossRef]

26. World Health Organization; Food and Agriculture Organization of the United Nations; World Organisation for Animal Health. Monitoring Global Progress On Addressing Antimicrobial Resistance; WHO: Geneva, Switzerland, 2018.

27. Bakkeren, E.; Huisman, J.S.; Fattinger, S.A.; Hausmann, A.; Furter, M.; Egli, A.; Slack, E.; Sellin, M.E.; Bonhoeffer, S.; Regoes, R.R.; et al. Salmonella Persisters Promote the Spread of Antibiotic Resistance Plasmids in the Gut. Nature 2019, 573, 276-280. [CrossRef] [PubMed]

28. Polianciuc, S.I.; Gurzău, A.E.; Kiss, B.; Stefan, M.G.; Loghin, F. Antibiotics in the Environment: Causes and Consequences. Med. Pharm. Rep. 2020. [CrossRef] [PubMed]

29. Gambino, D.; Persichetti, M.F.; Gentile, A.; Arculeo, M.; Visconti, G.; Currò, V.; Caracappa, G.; Crucitti, D.; Piazza, A.; Mancianti, F.; et al. First Data on Microflora of Loggerhead Sea Turtle (Caretta Caretta) Nests from the Coastlines of Sicily. Biol. Open 2020, 9, bio045252. [CrossRef]

30. Blasi, M.F.; Migliore, L.; Mattei, D.; Rotini, A.; Thaller, M.C.; Alduina, R. Antibiotic Resistance of Gram-Negative Bacteria from Wild Captured Loggerhead Sea Turtles. Antibiotics 2020, 9, 162. [CrossRef]

31. Zhang, Y.; Wang, J.; Lu, J.; Wu, J. Antibiotic Resistance Genes Might Serve as New Indicators for Wastewater Contamination of Coastal Waters: Spatial Distribution and Source Apportionment of Antibiotic Resistance Genes in a Coastal Bay. Ecol. Indic. 2020, 114, 106299. [CrossRef]

32. Yukawa, S.; Uchida, I.; Tamura, Y.; Ohshima, S.; Hasegawa, T. Characterisation of Antibiotic Resistance of Salmonella Isolated from Dog Treats in Japan. Epidemiol. Infect. 2019, 147, e102. [CrossRef]

33. Nguyen Thi, H.; Pham, T.-T.-T.; Turchi, B.; Fratini, F.; Ebani, V.V.; Cerri, D.; Bertelloni, F. Characterization of Salmonella Spp. Isolates from Swine: Virulence and Antimicrobial Resistance. Animals 2020, 10, 2418. [CrossRef]

34. Sucato, A.; Vecchioni, L.; Savoca, D.; Presentato, A.; Arculeo, M.; Alduina, R. A Comparative Analysis of Aquatic and PolyethyleneAssociated Antibiotic-Resistant Microbiota in the Mediterranean Sea. Biology 2021, 10, 200. [CrossRef] [PubMed]

35. Aldema, M.L.; McMurry, L.M.; Walmsley, A.R.; Levy, S.B. Purification of the Tn10-Specified Tetracycline Efflux Antiporter TetA in a Native State as a Polyhistidine Fusion Protein. Mol. Microbiol. 1996, 19, 187-195. [CrossRef]

36. Roberts, M.C. Update on Acquired Tetracycline Resistance Genes. FEMS Microbiol. Lett. 2005, 245, 195-203. [CrossRef]

37. Bryan, A.; Shapir, N.; Sadowsky, M.J. Frequency and Distribution of Tetracycline Resistance Genes in Genetically Diverse, Nonselected, and Nonclinical Escherichia Coli Strains Isolated from Diverse Human and Animal Sources. Appl. Environ. Microbiol. 2004, 70, 2503-2507. [CrossRef] [PubMed]

38. Tawyabur, Md.; Islam, Md.S.; Sobur, Md.A.; Hossain, Md.J.; Mahmud, Md.M.; Paul, S.; Hossain, M.T.; Ashour, H.M.; Rahman, Md.T. Isolation and Characterization of Multidrug-Resistant Escherichia Coli and Salmonella Spp. from Healthy and Diseased Turkeys. Antibiotics 2020, 9, 770. [CrossRef]

39. Koo, H.-J.; Woo, G.-J. Distribution and Transferability of Tetracycline Resistance Determinants in Escherichia Coli Isolated from Meat and Meat Products. Int. J. Food Microbiol. 2011, 145, 407-413. [CrossRef] [PubMed]

40. Jones, C.S.; Osborne, D.J.; Stanley, J. Enterobacterial Tetracycline Resistance in Relation to Plasmid Incompatibility. Mol. Cell. Probes 1992, 6, 313-317. [CrossRef]

41. Roberts, M.C. Epidemiology of Tetracycline-Resistance Determinants. Trends Microbiol. 1994, 2, 353-357. [CrossRef]

42. McDermott, P.F.; Zhao, S.; Tate, H. Antimicrobial Resistance in Nontyphoidal Salmonella. Microbiol. Spectr. 2018, 6. [CrossRef]

43. Soares, F.B.; Camargo, C.H.; Cunha, M.P.V.; de Almeida, E.A.; de Jesus, A.M.B.; de Carvalho, E.; de Paiva, J.B.; Fernandes, S.A.; Tiba-Casas, M.R. Subtyping of Plasmid-Mediated Quinolone Resistance among Salmonella Serotypes by Whole Genome Sequencing. Diagn. Microbiol. Infect. Dis. 2019, 94, 403-406. [CrossRef] [PubMed]

44. Lian, X.; Wang, X.; Liu, X.; Xia, J.; Fang, L.; Sun, J.; Liao, X.; Liu, Y. OqxAB-Positive IncHI2 Plasmid PHXY0908 Increase Salmonella Enterica Serotype Typhimurium Strains Tolerance to Ciprofloxacin. Front. Cell. Infect. Microbiol. 2019, 9, 242. [CrossRef] [PubMed]

45. Munita, J.M.; Arias, C.A. Mechanisms of Antibiotic Resistance. Microbiol. Spectr. 2016, 4. [CrossRef]

46. Gambino, D.; Vicari, D.; Vitale, M.; Schirò, G.; Mira, F.; Giglia, M.L.; Riccardi, A.; Gentile, A.; Giardina, S.; Carrozzo, A.; et al. Study on Bacteria Isolates and Antimicrobial Resistance in Wildlife in Sicily, Southern Italy. Microorganisms 2021, 9, 203. [CrossRef] [PubMed]

47. Alduina, R.; Gambino, D.; Presentato, A.; Gentile, A.; Sucato, A.; Savoca, D.; Filippello, S.; Visconti, G.; Caracappa, G.; Vicari, D.; et al. Is Caretta Caretta a Carrier of Antibiotic Resistance in the Mediterranean Sea? Antibiotics 2020, 9, 116. [CrossRef]

48. Jiang, H.; Zhou, R.; Yang, Y.; Chen, B.; Cheng, Z.; Zhang, M.; Li, J.; Zhang, G.; Zou, S. Characterizing the Antibiotic Resistance Genes in a River Catchment: Influence of Anthropogenic Activities. J. Environ. Sci. 2018, 69, 125-132. [CrossRef]

49. Issenhuth-Jeanjean, S.; Roggentin, P.; Mikoleit, M.; Guibourdenche, M.; de Pinna, E.; Nair, S.; Fields, P.I.; Weill, F.-X. Supplement 2008-2010 (No. 48) to the White-Kauffmann-Le Minor Scheme. Res. Microbiol. 2014, 165, 526-530. [CrossRef]

50. CLSI. Performance Standards for Antimicrobial Disk and Dilution Susceptibility Tests for Bacteria Isolated from Animals CLSI Supplement VET08, 4th ed.; Committee for Clinical and Laboratory Standards Institute: Wayne, PA, USA, 2018; ISBN 978-1-68440-010-2.

51. Lynne, A.M.; Rhodes-Clark, B.S.; Bliven, K.; Zhao, S.; Foley, S.L. Antimicrobial Resistance Genes Associated with Salmonella Enterica Serovar Newport Isolates from Food Animals. Antimicrob. Agents Chemother. 2008, 52, 353-356. [CrossRef] 
52. Ahmed, A.M.; Shimamoto, T.; Shimamoto, T. Molecular Characterization of Multidrug-Resistant Avian Pathogenic Escherichia Coli Isolated from Septicemic Broilers. Int. J. Med. Microbiol. 2013, 303, 475-483. [CrossRef] [PubMed]

53. Zambri, M.; Cloutier, M.; Adam, Z.; Lapen, D.R.; Wilkes, G.; Sunohara, M.; Topp, E.; Talbot, G.; Khan, I.U.H. Novel Virulence, Antibiotic Resistance and Toxin Gene-Specific PCR-Based Assays for Rapid Pathogenicity Assessment of Arcobacter Faecis and Arcobacter Lanthieri. BMC Microbiol. 2019, 19, 11. [CrossRef] [PubMed] 